\title{
SCALE AND TIMING CONSTRAINTS ON CHEMICAL REDISTRIBUTION BETWEEN MINERALS OF A COMPOSITE GARNET PERIDOTITE/ORTHOPYROXENITE
}

\author{
Lahaye, Y. and Brey, G.P. \\ University of Frankfurt, Germany
}

\section{INTRODUCTION}

Detailed petrological investigations and studies of the isotopic and major and trace element composition of peridotites and its constituents indicate a complexity of processes which led to the present day mineral and chemical composition of upper mantle samples. Most of the evidence is circumstantial and rarely are samples available where such processes are frozen in and can be studied in detail. In a recent collection campaign at Boshop road dumps in Kimberley (South Africa), an unusual type of composite garnet lherzolite xenoliths has been collected. These lherzolites are characterised by vein-like structures or patches of orthopyroxenite with several centimetre sized crystals with strings and tabular rods of garnet at grain rims and along cleavages. A detailed petrological and geochemical study of such samples should cast some light on the scale and timing of chemical redistribution between minerals and on processes which led to the unusually orthopyroxenerich nature of the cratonic mantle samples from the Kaapvaal craton.

\section{RESULTS AND DISCUSSION}

\section{Petrography (Fig. 1)}

The xenolith with about $25 \mathrm{~cm}$ diameter from which the hand-sized specimen shown in Fig. 1 was cut off consisted of an elongated patch of orthopyroxenite on one side and mostly of an equigranular garnet peridotite. The slice in Fig. 1 shows these two distinct units ( 1 = orthopyroxenite and 3 = granular peridotite) which are separated by a diffuse aureole ( 3 in Fig. 1) of olivine (partly serpentinised) in minor amounts + opx + roundish garnet grains. Five consecutive polished thin sections were produced across the three areas. In the orthopyroxenite, garnet exsolves from the centimetre sized elongated orthopyroxenes and partly recrystallizes in an alignment of round grains. It makes up about $5 \%$ of the mineralogy. A small amount of olivine is observed in the middle of the orthopyroxenite and rare, round grains of chrome diopside also occur in places in the orthopyroxenite. The aureole consists of increased amounts of olivine and roundish grains of individual garnets. The texturally equilibrated granular garnet peridotite host is composed of equal proportion of olivine and orthopyroxene with minor amount of garnet $(<5 \%)$. Pockets of phlogopite up to $1 \mathrm{~cm}$ occur in all three parts of the xenolith. A late stage alteration process, probably related to interaction with the kimberlite magma brings in small melt pods and apatite and triggers a reaction to form small euhedral spinels and new granular orthopyroxenes at the contacts and at the edges of the original orthopyroxene grains. This pervasive late fluid circulation seems nevertheless to be focussed in the aureole at the contact between orthopyroxenite and garnet peridotite.

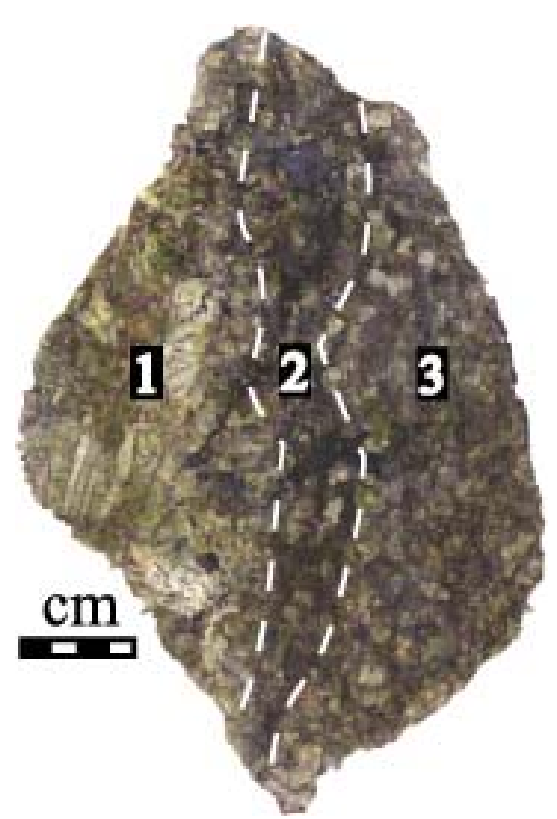

Figure 1: Hand-sized slice cut off from a composite garnet lherzolite xenolith from the Boshop road dumps. The sample is divided in parts: (1) an orthopyroxenite; (2) a diffuse transition zone; (3) a equigranular garnet peridotite host.

\section{Analytical techniques}

The major-element composition of minerals was determined by electron microprobe using a $15 \mathrm{kV}$ accelerating voltage and a $20 \mathrm{nA}$ beam current with a beam of 3 $\mu \mathrm{m}$ in diameter. The trace elements were determined by laser ablation inductively coupled plasma mass spectrometry (LA-ICP-MS), using a New Wave Research 
LUV213 ${ }^{\mathrm{TM}}$ petrographic ultraviolet Nd-YAG laser coupled with a Finnigan MAT ELEMENT2 ${ }^{\mathrm{TM}}$. The laser was run at a pulse frequency of $10 \mathrm{~Hz}$ and a pulse energy of $0.5 \mathrm{~mJ}$ for a $70 \mu \mathrm{m}$ spot size for the measurement of garnet and phlogopite. A $200 \mu \mathrm{m}$ spot size has been used for olivine and orthopyroxene. The USGS BIR1-G glass was used as an external standard for orthopyroxene and olivine with the concentrations taken from Eggins et al (1997). NIST612 (concentrations from Pearce et al., 1997) was the external standard for the other minerals. Silica was used as an internal standard for all measurements.

\section{Mineral Chemistry}

The Mg-values of both olivine and orthopyroxene are $93.5 \% \pm 0.16(2 \sigma)$ and of garnet $76.5 \% \pm 0.12(2 \sigma)$ irrespective to which part of the sample they belong (as illustrated in Fig. 2). This remarquable major element homogeneity is in contrast to the textural variability. Garnet with $5.1 \% \mathrm{CaO}$ and $4.8 \% \mathrm{Cr}_{2} \mathrm{O}_{3}$ just plots at the lower edge of the lherzolite field which may indicate clinopyroxene saturation. Yet, rare chrome diopside has a rounded shape and its composition with only $19.6 \% \mathrm{CaO}$ is such that it cannot be in equilibrium with orthopyroxene with $0.35 \%$. Phlogopite with its rather high $\mathrm{Mg}$-value and $\mathrm{Cr}_{2} \mathrm{O}_{3}$ content belongs to the primary mineral assemblage.

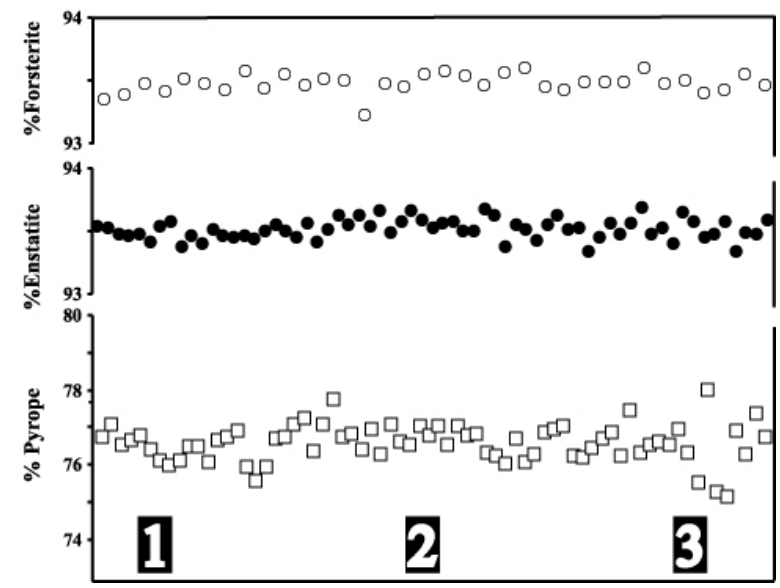

Figure 2: Mg-values of olivines, orthopyroxenes and garnets across the sample

Average trace element concentrations are given in table 1 and presented in spidergrams normalised to the primitive mantle values of Hofmann (1988) - see Figs. 3 and 4. Like the major elements, trace elements in garnet are also very homogeneous except for a few examples, where $\mathrm{La}$ and $\mathrm{Ce}$ and the very incompatible elements show elevated levels. The shape of the REE pattern is sigmoidal as it is well known from inclusions in diamonds and from xenoliths (Stachel et al., 2003). The overall abundance of the HREE is low.

\begin{tabular}{cccccccc}
\hline & Gt & Ol & $\mathbf{O p x}$ & Phl & $\mathbf{C p x}$ & Sp & Ap \\
\hline $\mathbf{n}$ & 70 & 34 & 65 & 7 & 3 & 8 & 1 \\
\hline $\mathbf{S i O}_{\mathbf{2}}$ & 41.7 & 40.9 & 57.4 & 40.2 & 53,9 & 0.10 & 0.42 \\
$\mathbf{T i O}_{\mathbf{2}}$ & 0.02 & 0.01 & 0.01 & 0.3 & 0,24 & 0.37 & 0.01 \\
$\mathbf{A l}_{\mathbf{2}} \mathbf{O}_{\mathbf{3}}$ & 20.2 & 0.03 & 0.79 & 14.3 & 3,3 & 34.6 & 0.04 \\
$\mathrm{Cr}_{\mathbf{2}} \mathbf{O}_{\mathbf{3}}$ & 4.8 & 0.02 & 0.37 & 1.20 & 0,5 & 34.6 & 0.00 \\
$\mathbf{F e O}$ & 6.5 & 6.5 & 4.0 & 2.5 & 2,7 & 12.4 & 0.31 \\
$\mathbf{M n O}$ & 0.35 & 0.09 & 0.10 & 0.02 & 0,15 & 0.21 & 0.02 \\
$\mathbf{N i O}$ & 0.01 & 0.42 & 0.10 & 0.22 & 0,03 & 0.20 & 0.02 \\
$\mathbf{M g O}$ & 21.4 & 52.6 & 36.9 & 25.8 & 18,7 & 19.2 & 0.74 \\
$\mathbf{C a O}$ & 5.12 & 0.02 & 0.35 & 0.01 & 19,6 & 0.01 & 47.1 \\
$\mathbf{N a} \mathbf{2}$ & 0.03 & 0.02 & 0.09 & 0.44 & 1,24 & 0.02 & 0.74 \\
$\mathbf{K}_{2} \mathbf{O}$ & 0.00 & 0.00 & 0.00 & 9.7 & 0,04 & 0.01 & 0.02 \\
$\mathbf{P}_{\mathbf{2}} \mathbf{O}_{\mathbf{5}}$ & 0.08 & 0.02 & 0.01 & 0.01 & 0,03 & 0.01 & 38.5 \\
\hline $\mathbf{T o t a l}$ & 100.2 & 100.7 & 100.2 & 94.7 & 100,5 & 101.8 & 87.9 \\
\hline
\end{tabular}

\begin{tabular}{ccccc}
\hline $\mathbf{n}$ & 47 & 15 & 30 & 5 \\
\hline $\mathbf{L i}$ & 0.76 & 1.04 & 0.70 & 0.51 \\
$\mathbf{S c}$ & 112 & 0.69 & 1.57 & 0.77 \\
$\mathbf{N i}$ & 38 & 3465 & 849 & 2447 \\
$\mathbf{R b}$ & 0.29 & 0.11 & 0.18 & 353 \\
$\mathbf{S r}$ & 2.56 & 6.93 & 4.33 & 45.13 \\
$\mathbf{Y}$ & 3.38 & 0.00 & 0.03 & 0.04 \\
$\mathbf{Z r}$ & 91 & 0.36 & 1.01 & 2.87 \\
$\mathbf{N b}$ & 1.89 & 1.24 & 0.75 & 22.74 \\
$\mathbf{B a}$ & 4.18 & 0.15 & 1.65 & 5011 \\
$\mathbf{L a}$ & 0.19 & 0.003 & 0.248 & 0.028 \\
$\mathbf{C e}$ & 0.84 & 0.005 & 0.663 & 0.013 \\
$\mathbf{P r}$ & 0.36 & 0.002 & 0.063 & 0.009 \\
$\mathbf{N d}$ & 4.64 & 0.005 & 0.280 & 0.047 \\
$\mathbf{S m}$ & 3.13 & 0.007 & 0.057 & 0.040 \\
$\mathbf{E u}$ & 1.22 & 0.003 & 0.015 & 0.025 \\
$\mathbf{G d}$ & 3.54 & 0.004 & 0.035 & \\
$\mathbf{T b}$ & 0.35 & & & \\
$\mathbf{D y}$ & 1.18 & 0.004 & 0.016 & 0.047 \\
$\mathbf{H o}$ & 0.13 & 0.001 & 0.003 & 0.005 \\
$\mathbf{E r}$ & 0.25 & 0.003 & 0.007 & 0.038 \\
$\mathbf{T m}$ & 0.03 & & & \\
$\mathbf{Y b}$ & 0.24 & 0.004 & 0.004 & 0.024 \\
$\mathbf{L u}$ & 0.05 & 0.002 & 0.001 & 0.005 \\
$\mathbf{H f}$ & 1.29 & 0.007 & 0.029 & 0.103 \\
$\mathbf{T a}$ & 0.02 & 0.027 & 0.032 & 0.915 \\
$\mathbf{T h}$ & 0.05 & 0.041 & 0.050 & 0.152 \\
$\mathbf{U}$ & 0.03 & 0.004 & 0.015 & 0.032 \\
\hline & & & &
\end{tabular}

Table 1: Major and trace elements of garnet (Gt), olivine $(\mathrm{Ol})$, orthopyroxene $(\mathrm{Opx})$, phlogopite $(\mathrm{Phl})$, clinopyroxene (cpx), spinel (Sp), apatite (Ap); major elements in wt.\% and trace elements in ppm; $\mathrm{n}=$ number of analyses 


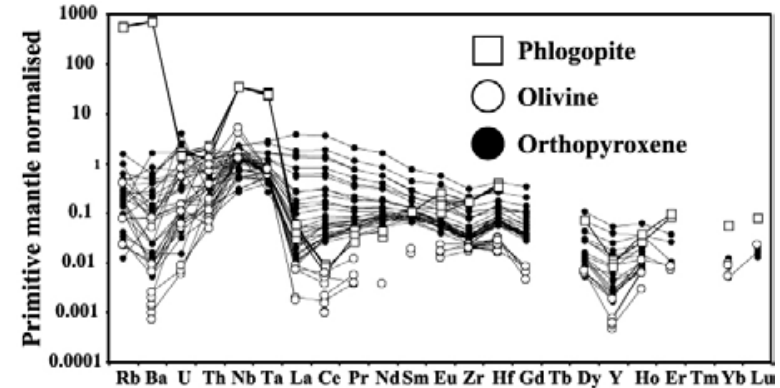

Figure 3: Spidergram representing the primitive mantle normalized concentrations of phlogopite (open square), olivine (open circle) and orthopyroxene (black circle)

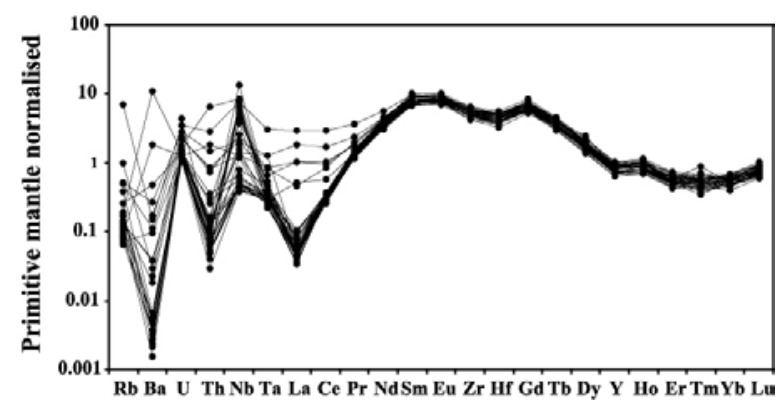

Figure 4: Spidergram representing the primitive mantle normalized concentrations of the garnet.

REE in orthopyroxenes are generally also quite constant except for the LREE which tend to decrease towards the garnets (in part 1 of the sample). The patterns and the low abundances of REE in the orthopyroxenes appear complementary to garnet and indicate equilibrium between these two phases. Olivines are the most depleted in the elements shown in the spidergrams. Phlogopite has REE abundances in the range of the orthopyroxenes but shows a sigmoidal pattern as the garnets. Most noticeable are the high abundances of $\mathrm{Nb}$ and $\mathrm{Ta}$, a feature which is also reflected in the garnets, orthopyroxenes and olivines. The high abundances of $\mathrm{Nb}$ and $\mathrm{Ta}$ in phlogopite demonstrate the mobility of these reputedly immobile elements.

\section{Thermobarometry}

The average major element composition of the minerals present are given in Table 1. Because of their homogeneity these values have been taken to calculate pressures and temperatures of final crystallisation. We employed the combinations $\mathrm{T}_{\text {Harley }}(=\mathrm{Fe}-\mathrm{Mg}$-exchange between opx and garnet after Harley, 1984) with $P_{B K N}$ (Al-in-opx barometer after Brey and Koehler, 1990) and $\mathrm{T}_{\mathrm{O} \text { 'Neill }}$ (Fe-Mg exchange between olivine and garnet after O'Neill, 1979) with $\mathrm{P}_{\mathrm{BKN}}$, which gave 915 ${ }^{\circ} \mathrm{C}$ and 35.5 kbar respectively $910^{\circ} \mathrm{C}$ and $35 \mathrm{kbar}$.

Calculated equilibrium temperature for the unique $\mathrm{Cpx} / \mathrm{Opx}$ pair provided temperatures up to $1200^{\circ} \mathrm{C}$ at $50 \mathrm{kbar}$ which we do not consider meaningful since clinopyroxene is evidently not in equilibrium with the rest of the paragenesis.

\section{Conclusion}

Homogeneity of major and trace elements throughout the sample is in sharp contrast with the textural inhomogeneity, which suggests a dynamic process of intrusion and precipitation at high temperatures, local chemical variations and subsequent cooling accompanied by exsolution of garnet. Garnets should be different in composition depending on whether they occur as exsolutions from orthopyroxenes or in the peridotite matrix. This is clearly not the case and alternative explanations have to be sought.

One of the most prominent features of granular peridotites from the Kaapvaal craton is their orthopyroxene rich nature compared to those from the oceanic lithosphere (Boyd, 1989). This feature has been explained by various models, the most prominent being silification of the residual continental mantle via melt/rock interaction (Keleman et al., 1998). Yaxley and Green (1998) produced experimental evidence that such a process is viable. They especially showed that a pervasive rhyodacitic melt originated by partial melting of eclogite is taken up entirely in peridotite leaving its traces in layers of orthopyroxene and in general enrichment of peridotite in orthopyroxene. The sample presented here is considered as the actual witness of such a process from the earth mantle: a highly depleted harzburgite consisting of only olivine and orthopyroxene and with a LREE depleted pattern and low abundances in REE was pervasively intruded by rhyodacitic melt enriched in LREE and other highly incompatible elements, but poor in compatible elements and also $\mathrm{Ca}$ and $\mathrm{Fe}$. Local modal inhomogeneities were created possible along original passage ways of the melt but also because of pre-existing layering. Chemical composition of the minerals grown by this reaction process at high temperatures was, however, identical in all parts. Subsequent cooling led to the exsolution of garnet from orthopyroxene which may have run to complete recrystallisation in the olivine rich part because of possible smaller grain sizes of the orthopyroxenes and to strings of exsolved garnet in the coarse grained, opx-rich part. The sigmoidal REE patterns in garnet are the result of exsolution from orthopyroxene at equilibrium. This orthopyroxene was 
previously enriched in LREE and incompatible elements at high temperature during interaction of a depleted peridotite with a silicic melt. Phlogopite and olivine also adjusted continuously in their composition to changing physical conditions.

\section{Acknowledgements}

We thank DeBeers Consolidated Mines Ltd and Bill McKechnie for their hospitality and Jock Robey for the tremendous support we experienced at Kimberley.

\section{REFERENCES}

Boyd, F.R., 1989. Compositional distinction between oceanic and cratonic lithosphere. Earth and Planetary Science Letters, 96: 15-26.

Brey, G.P., Köhler, T., 1990. Geothermobarometry in four-phase lerzholites II. New thermobarometers, and practical assessment of existing thermobarometers. J. Petrology, 31: 1353-1378.

Eggins, S.M., Woodhead, J.D., Kinsley, L.P.J., Mortimer, G.E., Sylvester, P., McCulloch, M.T., Hergt, J.M., Handler, M.R., 1997. A simple method for the precise determination of $>40$ trace elements in geological sample by ICPMS using enriched isotope internal standardization. Chemical Geology, 134: 311-326.

Harley, S.L., 1984. An experimental study of the partitioning of $\mathrm{Fe}$ and $\mathrm{Mg}$ between carnet and orthopyroxene, Contribution to Mineralogy and Petrology, 86: 359-373.

Hofmann, A. W., 1988. Chemical differentiation of the Earth : the relationship between mantle, continental crust and oceanic crust. Earth and Planetary Science Letters, 90: 297-314.

Keleman, P.B., Hart, S.R., Bernstein, S., 1998. Silica enrichment in the continental upper mantle via melt/rock reaction. Earth and Planetary Science Letters, 164: 387-406.

O’Neill, H.St.C., Wood, B.J., 1979. An experimental study of Fe-Mg partitioning between carnet and olivine and its calibration as a geothermometer, Contribution to Mineralogy and Petrology, 70: 59-70.

Pearce, N.J.G., Perkins, W.T., Westgate, J.A., Gorton, M.P., Jackson, S.E., Neal, C.R., Chenery, S.P., 1997. A compilation of new and published major and trace element data for NIST SRM 610 and NIST SRM 612 glass reference materials. Geostandards Newsletter, 21: 115-144.

Stachel, T., Aulbach, S., Brey, G.P., Harris, J.W., Leost, I., Tappert, R., 2003. Diamond formation and mantle metasomatism: a trace element perspective. This volume.

Yaxley, G., Green, D.H., 1998. Reaction between eclogites and peridotite: mantle refertilisation by subduction of oceanic crust. Schweiz. Mineral. Petrogr. Mitt., 78: 243-255.

Contact: Yann Lahaye, Institut für Mineralogie, Universität Frankfurt, 60054 Frankfurt, Germany, e-mail: lahaye@em.uni-frankfurt.de 